Сремесва Н.С.

ORCID ID: 0000-0003-1950-501X

Зозульов О.В.

канд. економ. наук, професор

ORCID ID: 0000-0001-7087-2080

Національний технічний університет України

«Київський політехнічний інститут імені Ігоря Сікорського»

\title{
ОСОБЛИВОСТІ ЕЛЕКТРОННОГО БІЗНЕСУ НА РИНКУ ВЕТЕРИНАРНИХ ПРЕПАРАТІВ
}

\section{ОСОБЕННОСТИ ЭЛЕКТРОННОГО БИЗНЕСА НА РИНКЕ ВЕТЕРИНАРНЫХ ПРЕПАРАТОВ}

\section{THE PECULIARITIES OF ELECTRONIC BUSINESS \\ ON THE VETERINARY MEDICINES MARKET}

У статті розглядається підходи до визначення поняття «електронний бізнес», структура електронного бізнесу та його складові частини. Визначається дев'ять форм організачії взаємодії між суб'єктами ринкових відносин: виробниками та споживачами контенту у прочесі організації електронного бізнесу. Наводиться авторська класифікація стратегій ведення електронного бізнесу за такими критеріями: виконання функиії, розмішення, використовувані технології, спрямованість, напрямок, тип стратегії та підхід. Показано зв'язок ветеринарного ринку зі спорідненими товарними ринками. Визначено структуру споживачів ветеринарного ринку на споживчому та промисловому ринках. Виявлено проблеми дослідження ринку ветеринарних препаратів. Проводиться порівняльна характеристика ветеринарного та фармацевтичного ринків на основі законодавчої бази Украӥни. На основі досліджень наводяться особливості електронного бізнесу на ринку ветеринарних препаратів за такими елементами як: реклама, консультування, логістика, банкінг та формування стратегії.

Ключові слова: електронний бізнес, ветеринарні препарати, інтернет-магазин.

B статье рассматриваются подходы $\kappa$ определению понятия «электронный бизнес», структура электронного бизнеса и его составные части. Определяются девять форм организачии взаимодействия между субъектами рыночных отночений: производителями и потребителями контента в процессе организации электронного бизнеса. Приводится авторская классификаџия стратегий ведения электронного бизнеса по следуюшим критериям: выполнение функиии, размещения, используемье технологии, направленность, направление, тип стратегии и подход. Показана связь ветеринарного рынка с родственными товарными рынками. Определена структура потребителей ветеринарного рынка на потребительском и промышленном рынках. Выявлены проблемы исследования рынка ветеринарных препаратов. Проводится сравнительная характеристика ветеринарного и фармацевтического рынков на основе законодательной базы Украины. На основе исследований приводятся особенности электронного бизнеса на рынке ветеринарных препаратов по следуюшим элементам как: реклама, консультирование, логистика, банкинг и формирования стратегии.

Ключевые слова: электронный бизнес, ветеринарные препараты, интернет-магазин. 
The article considers approaches to defining the concept of "e-business" e-business structure and its components. Identifies nine forms of interaction between the subjects of market relations: content producers and consumers in the process of e-business. We present the author's classification of strategies of e-business on the following criteria: the execution of the placement, the technology used, the direction, the direction, type of strategy and approach. The connection between the veterinary market with similar product markets. The structure of the veterinary market consumers in the consumer and industrial markets. The problems of research of the market of veterinary drugs. Held comparative characteristics of veterinary and pharmaceutical markets, based on the legal framework of Ukraine. On the basis of research are e-business features on the market of veterinary drugs on the following elements such as: advertising, consulting, logistics, banking and strategy formation.

Key words: e-business, veterinary medicines, an online shop.

Вступ. В сучасних умовах розвитку економіки, все більше підприємств стало використовувати інформаційну сферу в підприємництві. Ріст бізнес активності в інтернет просторі став одним із проявів так званої «нової економіки». I проблема організації електронного бізнесу набуває все більшого значення.

Проблемами електронного бізнесу займалися: Ананьєв О.М., Апопій В.В., Байдалюк Л.В., Бруннер М., Васильєва Н.Ф., Волков С., Гінкул А.С., Гурч Л., Кавура В.Л., Касатонова І.А., Кеглер Т., Коваленко О., Кравець В., Лебеденко М.С., Леонтьєв Б.К., Лігоненко Л., Нефьодов А., Онісіфорова В.Ю., Патраманська Л.Ю., Тардаскіна Т.М., Філіппова Л.Л., Черненко О.В., Шалева О.I.

Проблемами ринку ветеринарних препаратів займалися: Бушуєва I.B., Вербицький П.І., Гаврилюк О.Г., Гацан В.В., Карповський В.І., Косенко Ю.М., Коцюмбас І.Я., Мних О.Б., Тесляр Г.Ю., Тимошик Ю.В. Разом с тим залишається питання організації електронного бізнесу на ринку ветеринарних препаратів, що формує завдання цього дослідження.

Постановка завдання. Метою даного дослідження $\epsilon$ виявлення особливостей використання електронного бізнесу на ринку ветеринарних препаратів.

Методологія. В процесі дослідження використовувалися такі методи: монографічний, аналізу та синтезу, систематизації та узагальнення. Інформаційною базою дослідження стали наукові праці в галузі маркетингу та електронного бізнесу, Інтернет-джерела та дані підприємств.

Результати дослідження. Інформаційні мережі є середовищем, в якому відбуваються бізнес-процеси, та одночасно інфраструктурним забезпеченням електронного бізнесу[1]:

1. Інтранет (компанія) - підвищує ефективність взаємодії співробітників фірми, оптимізує процеси планування та прогнозування, прискорює документообіг між структурними підрозділами компанії, робить управління більш оперативним та ефективним; 
2. Екстранет (постачальники, клієнти, партнери) - поліпшує зовнішню взаємодію з партнерами у бізнесі (наприклад, постачання в режимі "just-intime"), сприяє кращій організації бізнес-процесів шляхом їх моделювання та моніторингу, робить можливим відособлення певних видів діяльності (outsourcing) і т.ін.;

3. Інтернет (весь світ) - $\epsilon$ універсальним діловим середовищем, що поєднало компанії між собою та 3 аудиторією споживачів, у ньому відбувається взаємодія всіх суб'єктів ринку щодо купівлі та продажу товарів і надання послуг.

У вітчизняній та зарубіжній літературі є різні підходи до визначення електронного бізнесу. За часту його ототожнюють з електронною комерцією $\mathrm{i}$ вважають ці поняття як синоніми (таблиця 1).

Таблиия 1

Визначення електронного бізнесу

\begin{tabular}{|c|c|c|}
\hline Підходи & Автори & Визначення \\
\hline 1 & 2 & 3 \\
\hline \multirow[t]{2}{*}{ Процесний } & $\begin{array}{c}\text { Спеціалісти компанії } \\
\text { IBM }\end{array}$ & $\begin{array}{l}\text { Процес використання } \\
\text { технологій для спрощення, поліпшення та } \\
\text { збільшення продуктивності виробничих } \\
\text { процесів, що надає можливість компаніям } \\
\text { легко контактувати } 3 \text { партнерами, } \\
\text { дилерами } \\
\text { та клієнтами, об'єднувати бази даних та } \\
\text { оперативно здійснювати свою діяльність, } \\
\text { тобто це перетворення основних бізнес- } \\
\text { процесів, підвищення їх ефективності за } \\
\text { допомогою інформаційно-комунікаційних } \\
\text { технологій. }\end{array}$ \\
\hline & $\begin{array}{c}\text { Управління торгівлі } \\
\text { Американського бюро } \\
\text { перепису } \\
\end{array}$ & $\begin{array}{l}\text { Будь-який процес, що здійснюється бізнес- } \\
\text { структурами за допомогою інформаційно- } \\
\text { комунікаційних технологій та мереж. }\end{array}$ \\
\hline Інтегральний & $\begin{array}{c}\text { Компанія "Price } \\
\text { Waterhouse Coopers" }\end{array}$ & $\begin{array}{l}\text { Інтеграцію систем, процесів, ланцюгів } \\
\text { створення вартості, часткових та } \\
\text { національних ринків за допомогою } \\
\text { технологій та концепцій, що базуються на } \\
\text { використанні Інтернету та пов'язані з ним. }\end{array}$ \\
\hline & $\begin{array}{l}\text { Онлайн-словник } \\
\text { Інтернету }\end{array}$ & 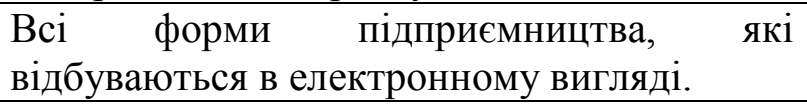 \\
\hline Комерційний & $\begin{array}{c}\text { Енциклопедія Інтернет- } \\
\text { бізнесу }\end{array}$ & $\begin{array}{l}\text { Представляє собою будь-яку ділову } \\
\text { активність, що використовує глобальні } \\
\text { інформаційні мережі для перетворення } \\
\text { внутрішніх та зовнішніх зв'язків } 3 \text { метою } \\
\text { отримання прибутку. }\end{array}$ \\
\hline
\end{tabular}

*Джерело: систематизовано авторами на основі [1],[2],[3]

Підсумовуючи наведені вище визначення, можна стверджувати, що електронний бізнес - це нова модель інтегрованої економічної діяльності, яка 
базується на використанні інформаційно-комунікаційних технологій та мереж як унікального макроекономічного середовища. 1).

Електронний бізнес охоплює всі види підприємницької діяльності (рис.

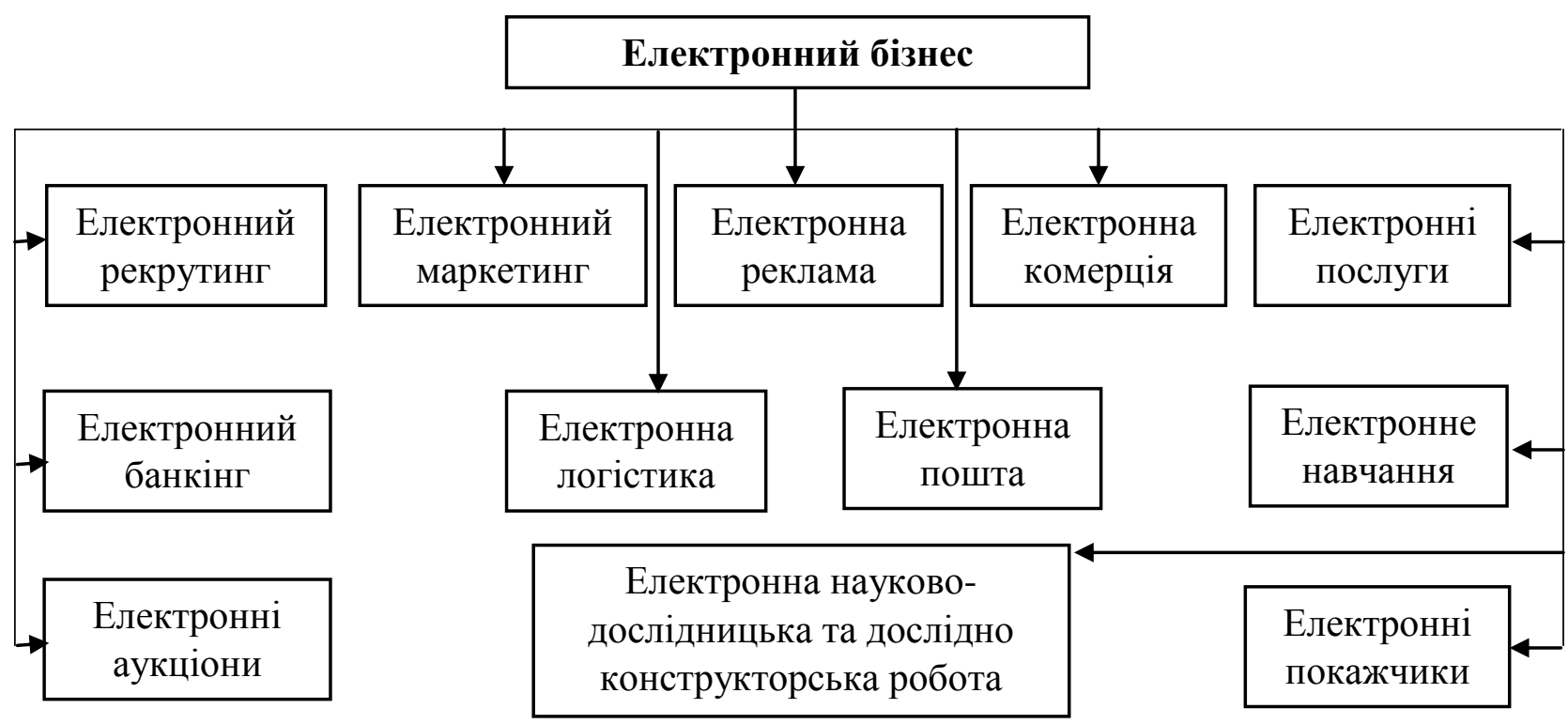

Рис. 1. Структура електронного бізнесу

Джерело: систематизовано авторами на основі [4]

Електронна комерція - комерційна взаємодія суб'єктів бізнесу з приводу купівлі-продажу товарів та послуг (матеріальних та інформаційних) 3 використанням інформаційних мереж (Інтернет, мережа стільникового зв'язку, внутрішні локальні мережі фірм)[5].

Електронний маркетинг - це комплекс соціальних та управлінських процесів, які спрямовані на якнайповніше задоволення потреб споживачів у мережі Інтернет при формуванні пропозиції і системи обміну товарів і послуг за допомогою інформаційних комунікаційних технологій[5].

Електронна реклама - це форма подання та поширення інформації в мережі Інтернет про товари та послуги з метою їх популяризації з указаним джерелом фінансування[5].

Аукціон - це спосіб продажу товарів, який базується на ціновій конкуренції між покупцями. Він є процедурою встановлення рівноважних цін на товар, при цьому ціну встановлює покупець, а продавець - правила, за якими має проводитися аукціон[5].

Електронний аукціон проводиться за тим же принципом в мережі Інтернет за допомогою спеціального програмного забезпечення, яке установлюється на сайті організатора торгу[5].

Електронний банкінг - це діяльність банку з надання комплексу послуг клієнтам за допомогою комп'ютерних технологій[5]. 
Електронний рекрутинг - це ряд інтернет-ресурсів, які надають різні сервіси в області пошуку персоналу і працевлаштування[5].

Електронний рекрутинг $є$ ключовою технологією в сучасному підборі персоналу.

Електронне навчання - це система навчання, побудована 3 використанням інформаційних та телекомунікаційних технологій, котрі в сучасних умовах широко використовуються як студентами, так і викладачами. Система електронного навчання дозволяе забезпечувати викладання навчальних курсів, отримувати інформацію та спілкуватися викладачам i студентам між собою незалежно від часу та місця знаходження[5].

Електронна пошта - електронна послуга, що надає змогу формувати, пересилати, зберігати та читати текстові документи, електронні таблиці в певному форматі, графічні файли, програми тощо та діє в режимі оффлайн[5].

Електронна логістика - керування та оптимізація електронних інформаційних потоків, що виникають у ланцюгах поставок. Базою електронної логістики є стандарти на кодування та зчитування інформації у логістичних системах. Підвищення ефективності керування перевізним процесом досягається за рахунок упровадження інформаційних систем, які дозволяють зменшувати кількість помилок при введенні даних, швидко передавати значні обсяги інформації, прискорити іiі обробку та зменшити кількості паперових носіїв[5].

Послуга - це товар особливого виду, діяльність, благо, що задовольняє потреби індивіда, виробництва або суспільства, має споживчу цінність і вартість, результат якої можу мати матеріальний i нематеріальний характер[5]. [5]:

Електронні продукти володіють такими специфічними властивостями

- Залежність від особистих уподобань, оскільки процес використання інформаційних продуктів має індивідуальний характер.

- Перехідна або кумулятивна корисність - більшість інформаційних продуктів залежать від часу, тому їх можна вважати "швидкопсувними". Разом $з$ тим попередні дні можуть застосовуватися для створення нових продуктів, тому їх корисність може накопичуватися, тобто $\epsilon$ кумулятивною.

- Економічні наслідки (як позитивні так i негативні від одночасного володіння продуктом значної кількості користувачів).

- Змінюваність (з позитивною і негативною метою).

- Методи виконання і передачі(реальним шляхом та інтерактивні).

Електронний бізнес включає в себе нові методи роботи компаній, що надає можливість забезпечити конкурентні переваги за рахунок зменшення видатків на взаємодію, розширення ринків і сфери діяльності та виявлення нових каналів збуту, залучення нових та поліпшення обслуговування старих 
клієнтів, більшої мобільності та оперативності при прийнятті управлінських рішень.

В електронному бізнесі присутні 9 форм взаємодії між виробниками, споживачами та урядом (таблиця 2).

Таблиця 2

Форми взаємодії

\begin{tabular}{|c|c|c|c|c|}
\hline & \multicolumn{4}{|c|}{ Постачальник контенту } \\
\hline \multirow{4}{*}{ 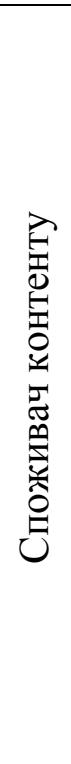 } & & Споживач & Виробник & Уряд \\
\hline & 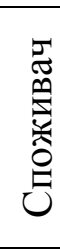 & $\begin{array}{c}\text { C2C } \\
\text { (соціальні мережі, інтернет- } \\
\text { аукціони, еВау, Aliexpress, } \\
\text { Skyре, дошки оголошень, } \\
\text { блоги) }\end{array}$ & $\begin{array}{c}\text { В2С } \\
\text { (медіа ресурси, } \\
\text { транзакційні, } \\
\text { агрегатори) }\end{array}$ & $\begin{array}{c}\mathrm{G} 2 \mathrm{C} \\
\text { (iнформаційні сайти та } \\
\text { портали уряду) }\end{array}$ \\
\hline & 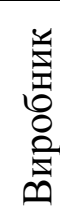 & $\begin{array}{c}\text { C2B } \\
\text { (зворотній зв'язок, crowd } \\
\text { funding) }\end{array}$ & $\begin{array}{c}\text { В2В } \\
\text { (медіа ресурси для } \\
\text { бізнесу, соціальні } \\
\text { мережі (Linked-in) }\end{array}$ & $\begin{array}{c}\text { G2B } \\
\text { (сервісні сайти уряду, } \\
\text { транзакційні (тендери)) }\end{array}$ \\
\hline & $\stackrel{\text { F }}{\stackrel{2}{\nu}}$ & $\begin{array}{c}\mathrm{C} 2 \mathrm{G} \\
\text { (зворотній зв’ язок, } \\
\text { електронні петиції) }\end{array}$ & $\begin{array}{c}\mathrm{B} 2 \mathrm{G} \\
\text { (зворотній зв'язок між } \\
\text { виробниками та } \\
\text { недержавними } \\
\text { організаціями) }\end{array}$ & $\begin{array}{c}\mathrm{G} 2 \mathrm{G} \\
\text { (електронний обмін } \\
\text { даними всередині } \\
\text { урядових сервісів) }\end{array}$ \\
\hline
\end{tabular}

* Джерело: систематизовано авторами на основі [4]

Виробник - споживач (B2C/C2B) - це форма взаємодії компаній зі споживачами та навпаки, яка надає виробникам додаткові можливості для просування своїх товарів та послуг безпосередньо до споживачів, а споживачам більше можливостей для вибору. Дана форма взаємодії була однією з перших стратегій електронного бізнесу, яка передбачає прямий рух товарів та послуг від виробників до кінцевих споживачів, обминаючи посередників.

Виробник - Виробник (В2В) - форма оперативної взаємодії підприємств на всіх рівнях, що орієнтується на діючий бізнес та на відпрацьовані схеми постачання та збуту, сталі внутрішні бізнес- процеси. Вона надає змогу об'єднати внутрішні мережі партнерів для спільного електронного документообігу, створює систему прямого розміщення замовлень 3 можливістю деталізації їх параметрів та відслідковування їх виконання в режимі реального часу і $є$ новим засобом більшості комунікації підприємств. Ця форма взаємодії набула сьогодні найбільшого поширення. На сектор В2В припадає біля 85 \% обороту електронного бізнесу.

Споживач - споживач (С2C) - взаємодія приватних осіб щодо купівліпродажу, обміну чи надання товарів, послуг та інформації в кіберпросторі.

Стратегії електронного бізнесу можна поділити на такі критерії: 
Класифікація стратегій ведення електронного бізнесу

\begin{tabular}{|c|c|c|}
\hline Критерї & Тип стратегії & Характеристика \\
\hline 1 & 2 & 3 \\
\hline \multirow{3}{*}{$\begin{array}{c}\text { 1. Виконання } \\
\text { функції }\end{array}$} & Інсорсінг & $\begin{array}{l}\text { Залучення внутрішніх ресурсів компанії в } \\
\text { нових цілях і проектах. }\end{array}$ \\
\hline & Краудсорсінг & $\begin{array}{l}\text { Залучення людей за допомогою } \mathrm{IT} \\
\text { технологій для вирішення } \\
\text { перед бізнесом, що стоять }\end{array}$ \\
\hline & Аутсорсінг & $\begin{array}{l}\text { Процес передачі компанії своєї частини } \\
\text { виробничих та бізнес процесів іншій } \\
\text { компанії, яка являється експертом в даній } \\
\text { сфері. }\end{array}$ \\
\hline \multirow{2}{*}{ 2. Розміщення } & $\begin{array}{c}\text { Власні } \\
\text { майданчики }\end{array}$ & $\begin{array}{l}\text { Продаж через власну мережу інтернет- } \\
\text { магазинів. }\end{array}$ \\
\hline & Колокація & $\begin{array}{l}\text { Передача прав та використання вже існуючих } \\
\text { інтернет-магазинів інших компаній. }\end{array}$ \\
\hline \multirow{2}{*}{$\begin{array}{c}\text { 3. Використовувані } \\
\text { технології }\end{array}$} & Традиційні & $\begin{array}{lll}\text { Збереження даних } & \text { безпосередньо } \\
\text { жорсткому диску. }\end{array}$ \\
\hline & Хмарні & $\begin{array}{llll}\text { Технологія, яка допускає обробку } & \text { та } \\
\text { збереження даних на віддалених серверах }\end{array}$ \\
\hline \multirow[t]{3}{*}{ 4. Спрямованість } & $\begin{array}{l}\text { Підвищення } \\
\text { ефективності }\end{array}$ & $\begin{array}{lccc}\text { Досягається } & \text { шляхом } & \text { економії } & \text { витрат, } \\
\text { поліпшення } & \text { іміджу } & \text { торгової } & \text { марки, } \\
\text { підвищення ефективності бізнес-процесів та } \\
\text { маркетингової діяльності компанії. }\end{array}$ \\
\hline & $\begin{array}{c}\text { Одержання } \\
\text { прямих доходів }\end{array}$ & $\begin{array}{l}\text { Продають у мережі безпосередньо товари чи } \\
\text { послуги, або рекламу. }\end{array}$ \\
\hline & Змішані & $\begin{array}{l}\text { Компанії мають } \\
\text { мережу } \text { Іногу викернет } 3 \text { метою пістовувати } \\
\text { ефективності своєї діяльності. }\end{array}$ \\
\hline \multirow{2}{*}{ 5. Напрямок } & Основний & $\begin{array}{l}\text { Використання інтернет-магазину, як єдиний } \\
\text { вид збуту. }\end{array}$ \\
\hline & Допоміжний & $\begin{array}{l}\text { Використання інтернет-магазину в поєднані } 3 \\
\text { оффлайновими магазинами. }\end{array}$ \\
\hline \multirow[b]{2}{*}{ 6. Тип стратегії } & Традиційна & Збут через оффлайнові магазини. \\
\hline & Мультиканальна & $\begin{array}{l}\text { Збут через декілька каналів збуту. Клієнт } \\
\text { може знайти потрібний йому товар через } \\
\text { мобільний інтернет, замовити } 3 \text { ноутбука, а } \\
\text { забрати в оффлайн магазині. }\end{array}$ \\
\hline \multirow[t]{2}{*}{ 7. Підхід } & Інтегрований & $\begin{array}{l}\text { Використовуються всі або декілька видів } \\
\text { електронного бізнесу, які доповнюють один } \\
\text { одне. }\end{array}$ \\
\hline & Селективний & $\begin{array}{l}\text { Використовуються окремі види електронного } \\
\text { бізнесу. }\end{array}$ \\
\hline
\end{tabular}

* Джерело: авторська розробка

Більшість компаній використовують селективний підхід ведення бізнесу. За часту вони впроваджують тільки якийсь окремий вид електронного 
бізнесу. Сучасна концепція побудови електронного бізнесу повинна включати всі його види: електронну комерцію, електронні комунікації, електронну логістику та навіть електронне навчання. Оскільки надалі розглядатиметься електронний бізнес на ринку ветеринарних препаратів, то треба зазначити, що електронне навчання буде відігравати значну роль, як допоміжна функція: проведення курсів по використанню ветеринарних препаратів.

Ринок ветеринарних препаратів і ринок лікарських засобів гуманної медицини тісно взаємопов'язані і формують фармацевтичний ринок, що $\epsilon$ частиною ринків хімічної продукції та біотехнологічної продукції. У той же час ринок ветеринарних препаратів $є$ частиною ринку засобів захисту здоров'я тварин. Сегменти ринку ветеринарних препаратів, призначених для сільськогосподарських тварин, $\epsilon$ складовими ринку товарів сільськогосподарського призначення, а сегменти ринку ветеринарних препаратів для домашніх тварин належать до ринку споживчих товарів.

На підставі аналізу розроблена модель, яка ілюструє місце ринку ветеринарних препаратів у системі товарних ринків (рис. 1).

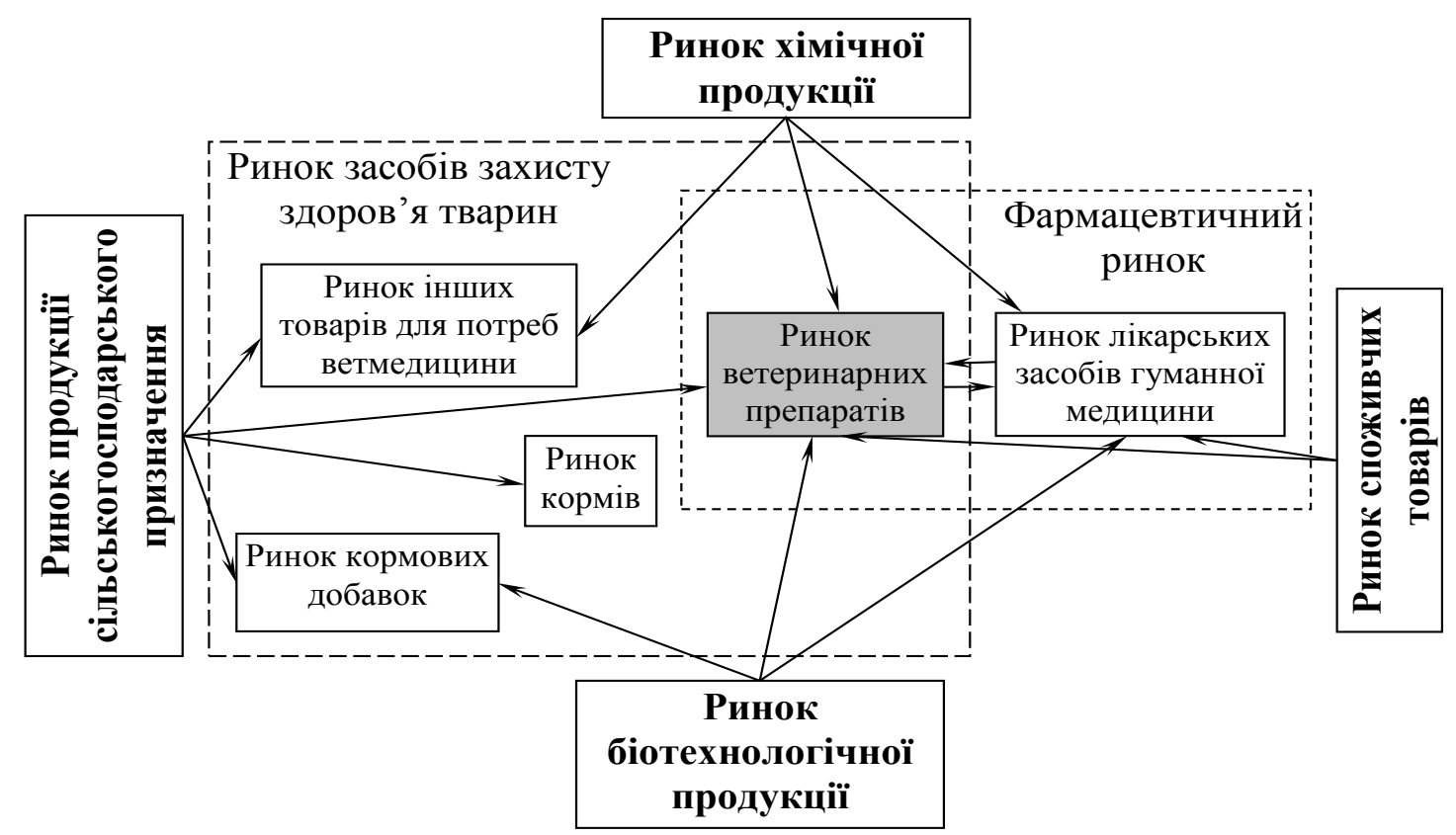

Рис. 2. Зв'язок ринку ветеринарних препаратів із спорідненими товарними ринками

Джерело: [6]

Особливостями ринку ветеринарних препаратів України є: потреба в ефективному державному регулюванні; висока наукомісткість галузі; вторинний попит; низька еластичність попиту; необхідність високого рівня захисту інформації; той фактор, що покупці не є споживачами; формування попиту відбувається спеціалістами ветеринарної медицини; потреба у специфічних препаратах; тісний взаємозв'язок з ринком лікарських засобів гуманної медицини; вплив морально-етичних норм[6]. 
Ринок ветеринарних препаратів складається 3 двох макросегментів: промислового і споживчого ринків.

\section{Ринок ветеринарних препаратів}

\section{Промисловий ринок:}

1. Виробники м'яса, молока, яєць

2. Племені господарі (господарський скот, конярство тощо.)

3. Організатори спортивних змагань тварин

4. Ветеринарні лікарні

\section{Споживчий ринок:}

1. Власники домашніх тварин

Рис. 3. Структура ринку споживачів ветеринарних препаратів Джерело: авторська розробка

Існують проблеми з дослідженням ринку ветеринарних препаратів. Це обумовлено такими причинами як:

1. Немає окремої статистики по даному ринку;

2. На ринку ветеринарної медицини, часто використовуються препарати гуманної медицини;

3. Немає моніторингу даного ринку.

Таблиия 4

Порівняння ветеринарного та фармацевтичного ринків

\begin{tabular}{|c|c|c|}
\hline Критерій & Ветеринарний ринок & Фармацевтичний ринок \\
\hline Суб’єкт & Тварини & Люди, тварини \\
\hline Предмет & Споріднена фармакінетика & Споріднена фармакінетика \\
\hline Спеціалізація & Широка & $\begin{array}{c}\text { Вузька (наявність великого } \\
\text { різновида лікарів) }\end{array}$ \\
\hline Випробування & Немає особливих вимог. & $\begin{array}{c}\text { Потребується дозвіл на } \\
\text { випробування. Доклінічні } \\
\text { випробування проводяться на } \\
\text { тваринах. Клінічні випробування } \\
\text { на людях з їх письмової згоди. }\end{array}$ \\
\hline $\begin{array}{c}\text { Державне } \\
\text { регулювання } \\
\text { допуску } \\
\text { препаратів }\end{array}$ & $\begin{array}{c}\text { Максимальний термін дії } \\
\text { реєстрації становить } 5 \text { років. }\end{array}$ & $\begin{array}{c}\text { Максимальний термін дії } \\
\text { реєстрації становить } 5 \text { років. }\end{array}$ \\
\hline $\begin{array}{c}\text { Система } \\
\text { дистрибуції }\end{array}$ & $\begin{array}{c}\text { Роздрібна торгівля ветеринарними } \\
\text { препаратами здійснюється лише } \\
\text { закладами ветеринарної медицини } \\
\text { та ветеринарними аптеками, які } \\
\text { мають ліцензію. } \\
\text { Підприємства, що здійснюють } \\
\text { оптову торгівлю ветеринарними } \\
\text { препаратами, можуть }\end{array}$ & $\begin{array}{c}\text { Оптова, роздрібна торгівля } \\
\text { лікарськими засобами на території } \\
\text { України здійснюється } \\
\text { підприємствами, установами, } \\
\text { організаціями та фізичними } \\
\text { особами - підприємцями на } \\
\text { підставі ліцензії, яка видається в } \\
\text { порядку, встановленому }\end{array}$ \\
\hline
\end{tabular}




\begin{tabular}{|c|c|c|}
\hline & $\begin{array}{c}\text { реалізовувати ці препарати } \\
\text { тільки іншим підприємствам з } \\
\text { оптового продажу, закладам } \\
\text { ветеринарної медицини та } \\
\text { ветеринарним аптекам. }\end{array}$ & законодавством. \\
\hline $\begin{array}{c}\text { Обмеження } \\
\text { допуску } \\
\text { використання } \\
\text { препарату }\end{array}$ & $\begin{array}{c}\text { Обов'язково потрібні мати ліцензії } \\
\text { на використання препаратів } \\
\text { наркотичної дії }\end{array}$ & $\begin{array}{c}\text { Обов’язково потрібні мати } \\
\text { ліцензії на використання } \\
\text { препаратів наркотичної дії }\end{array}$ \\
\hline $\begin{array}{c}\text { Характер } \\
\text { конкуренції }\end{array}$ & Нецінова конкуренція & Нецінова конкуренція \\
\hline Виробники & $\begin{array}{c}\text { Фармацевтичні та ветеринарні } \\
\text { компанії } \\
\end{array}$ & Фармацевтичні компанії \\
\hline $\begin{array}{l}\text { Обмеження по } \\
\text { купівлі } \\
\text { препарату }\end{array}$ & Без рецептурні & Рецептурні, безрецептурні \\
\hline $\begin{array}{l}\text { Замінність } \\
\text { препаратів }\end{array}$ & $\begin{array}{c}\text { Ветеринарні препарати можуть } \\
\text { бути замінені на препарати } \\
\text { гуманної медицини. } \\
\end{array}$ & Не можуть бути замінені. \\
\hline $\begin{array}{l}\text { Обмеження на } \\
\text { рекламну } \\
\text { діяльність }\end{array}$ & Не існує. & Існує на рецептурні препарати. \\
\hline $\begin{array}{l}\text { Обмеження на } \\
\text { організацію } \\
\text { продажу }\end{array}$ & $\begin{array}{c}\text { Наявність реєстрації інтернет- } \\
\text { магазину (відсутність реєстрації } \\
\text { призводить до адміністративної та } \\
\text { кримінальної відповідальності) та } \\
\text { наявність ліцензії на товар. }\end{array}$ & $\begin{array}{c}\text { Наявність реєстрації інтернет- } \\
\text { магазину (відсутність реєстрації } \\
\text { призводить до адміністративної та } \\
\text { кримінальної відповідальності) та } \\
\text { наявність ліцензії на товар. }\end{array}$ \\
\hline $\begin{array}{l}\text { Протоколи } \\
\text { лікування }\end{array}$ & Не існують. & Існують. \\
\hline
\end{tabular}

* Джерело: авторська розробка

В мережі Інтернет продавці лишені можливості прямого психологічного впливу на покупців, що з одного боку є плюсом, оскільки більшість людей не люблять, коли їм намагаються продати те, чого їм не потрібно і вони можуть самі зважено прийняти рішення.

Відвідати декілька онлайн магазинів значно легше, ніж об'їхати традиційні офлайнові магазини. Покупцям не треба витрачати багато часу.

Також плюсом $є$ те, що онлайн магазини доступні в будь-якій точці земної кулі, вони відкриті цілодобово. 
Табличя 5

Особливості електронного бізнесу на ринку ветеринарних препаратів

\begin{tabular}{|c|c|}
\hline Елемент е-бізнесу & Характеристика \\
\hline Реклама & $\begin{array}{l}\text { Не потребує вказання свідоцтва державної реєстрації, що економить } \\
\text { рекламний час. Розміщення реклами ефективне на ветеринарних } \\
\text { форумах, онлайн-зоомагазинах, сайтах компаній та у фахових } \\
\text { статтях. }\end{array}$ \\
\hline Консультування & $\begin{array}{l}\text { На ветеринарному ринку електронне консультування відіграє } \\
\text { важливу роль, оскільки препарати та їх спосіб застосування } \\
\text { змінюється, виробники розробляють щось нове, і не завжди є } \\
\text { можливість провести інструктаж зі всіма ветеринарними лікарями. } \\
\text { Електронне консультування дозволить лікарям швидко та зручно } \\
\text { дізнатися про специфіку нового препарату напряму від виробника не } \\
\text { покидаючи робочого місця. Перш за все консультування орієнтовано } \\
\text { на маленькі міста та село. Також консультування може проходити в } \\
\text { телефонному режимі при відсутності інтернету. }\end{array}$ \\
\hline Логістика & $\begin{array}{l}\text { Інтернет-магазин не потребує наявності оффлайнових магазинів. Для } \\
\text { охоплення максимальної території збуту потребується укладання } \\
\text { угоди з декілька кур’єрськими службами та наявності одного складу. }\end{array}$ \\
\hline Банкінг & $\begin{array}{l}\text { На даний час в Україні є складності з електронними платіжками, } \\
\text { оскільки ця система ще не розвинена. Інтернет-магазинам необхідно } \\
\text { укладати угоду з банками (найпопулярнішим являється ПриватБанк). }\end{array}$ \\
\hline $\begin{array}{l}\text { Формування } \\
\text { стратегії }\end{array}$ & $\begin{array}{l}\text { Використання таргетингу, ретаргетингу, лідогенерації, трекінгу, } \\
\text { інтерактивність. }\end{array}$ \\
\hline
\end{tabular}

* Джерело: авторська розробка

Використання даних елементів електронного бізнесу дозволить підприємству створити онлайн-зоомагазин та налагодити його ефективну роботу.

Висновки. Наукова новизна отриманих результатів полягає в тому що систематизовано підходи до визначення електронного бізнесу та його складові. Сформована авторська класифікація стратегій ведення електронного бізнесу, проведено порівняння ветеринарного та фармацевтичного бізнесу 3 точки зору організації електронного бізнесу. Наведені дані дозволяють підприємству розробити стратегію ведення бізнесу за допомогою електронної комерції.

\section{Література:}

1. Поняття та структура електронного бізнесу - [Електронний ресурс] - Режим доступу: http://www.frontmanagement.org/fomants-1014-1.html

2. IBM i електронний бізнес - [Електронний ресурс] - Режим доступу: http://www.ibm.com/ru/ebusiness/about_ebus.html

3. Тенденції та проблема розвитку електронного бізнесу в Україні - [Електронний ресурс] - Режим доступу: http://ukrefs.com.ua/page,2,114335-Tendenc-ta-problemi-rozvitkuelektronnogo-b-znesu-v-Ukra-n.html 
4. Електронний бізнес - [Електронний ресурс] - Режим доступу: http://bukvar.su/jekonomika/203262-Elektronnyiy-biznes.html

5. Шалева О.І. Електронна комерція - [Електронний ресурс] - Режим доступу: http://westudents.com.ua/knigi/209-elektronna-komertsya-shaleva-o.html

6. Формування та державне регулювання ринку ветеринарних препаратів в Україні [Електронний ресурс] - Режим доступу: http://www.ukrreferat.com/index.php?referat=69379\&pg=6 